\title{
Alice Munro: Writing for Dear Life. Introduction
}

\section{Corinne Bigot}

\section{(2) OpenEdition}

1 Journals

Electronic version

URL: https://journals.openedition.org/ces/4997

DOI: 10.4000/ces.4997

ISSN: 2534-6695

\section{Publisher}

SEPC (Société d'études des pays du Commonwealth)

\section{Printed version}

Date of publication: 1 April 2015

Number of pages: 5-9

ISSN: 2270-0633

\section{Electronic reference}

Corinne Bigot, "Alice Munro: Writing for Dear Life. Introduction", Commonwealth Essays and Studies

[Online], 37.2 | 2015, Online since 13 April 2021, connection on 17 July 2021. URL: http:// journals.openedition.org/ces/4997 ; DOl: https://doi.org/10.4000/ces.4997

\section{(c) (i) (9)}

Commonwealth Essays and Studies is licensed under a Licence Creative Commons Attribution - Pas d'Utilisation Commerciale - Pas de Modification 4.0 International. 


\section{Introduction}

In announcing the awarding of the Nobel Prize for Literature to Alice Munro in Stockholm on October $10^{\text {th }} 2013$, the Nobel Committee noted that Alice Munro's "texts often feature depictions of everyday but decisive events, epiphanies of a kind, that illuminate the surrounding story and let existential questions appear in a flash of lightning" ("bio-bibliography" np). As examples of such everyday life events, one may point out that Alice Munro's characters are depicted making, and mending clothes, or recycling them into rag rugs. Yet, they may also exhibit a dead woman's clothes ("The Peace of Utrecht") or hide secrets that may include loss of a child, accidental deaths, not to mention the fact that some of her characters do confess to having committed murders. Munro paints scenes that readers may identify as "scenes of life," relying on detailed descriptions including depictions of the smallest objects, or the most trivial ones, down to their cracks; she includes feelings and sensory details, even the most intimate ones. Narrators draw attention to annoyingly resilient stains, or burrs on a good dress, or a crust of porridge that has dried on the linoleum. They describe curtain and dress patterns. Munro herself has admitted that she writes stories that have "an awful lot of stuff that, by [the] strict standards [of the short story], are unnecessary in them" ("Interview") - an assertion which readers familiar with her fiction will greet with a smile. Yet analyses of her style show that she frequently relies on repetitions and accumulation, and that the narrative often operates on the digressive mode. Munro's fiction is a "fiction of admission" that tends to "include rather than to discard," as Helen Hoy argues in her seminal essay (5). Her landscape often features refuse dumps or refuse heaps, full of discards which characters may spend hours looking at ("Lying under the Apple Tree," The View from Castle Rock). Munro's depictions of women's bodies draw attention to their visible and invisible flaws such as discharges, warts, varicose veins, unsightly growths or hidden cysts and lumps, as catalogued by one of Munro's most famous narrators, would-be writer Del Jordan. Yet, Munro's lists, as Thomas Dutoit argues in a recent essay where he returns to what is surely one of Munro's most famous passages, Del Jordan's wish list in Lives of Girls and Women, ${ }^{1}$ are bored (perforated) rather than boring: "inscriptions will always be boring, bored, both insufficient and unrevealing [but] they will, simultaneously, be perforated by puncta" (86).

There is no denying that gaps, rifts, cracks and silences puncture her fiction, from her representation of cracked surfaces or deep holes in her landscape, to her portraits of women (and men) who are "full of mended cracks that you could only see close up" ("Carried Away" 37), to her narrator's accounts. In the introduction to a recent volume of essays on Munro's début collection, Michael Toolan reminds us that "there will be gaps, secrets, mysteries and lacunae, there will be causes and reasons that never quite come clear" (11). Such gaps and silences play a key role in Munro's fiction, as Judith

1. "And no list could hold what I wanted, for what I wanted was every last thing, every layer of speech and thought, stroke of light on bark or walls, every smell, pothole, pain, crack, delusion, held still and held together - radiant, everlasting" (Lives 249). 
Miller has argued, for Munro wants her readers to "wander into rifts, to find what might be in there," (208) for Munro will want "to find a way to open up rifts, spaces, where she suspects story really lingers" (208). It is no coincidence that Munro's landscape features gravel pits, gaps, mines, refuse heaps and snow-covered monstrous shapes as well as seemingly boring landscapes. In "What Do You Want to Know For?" from her 2006 collection, The View from Castle Rock, the narrator, a Munro persona, describes Ontario's rural landscape, reminding her readers of the dangers of dismissing it as "drab" agricultural landscape, since it hides and reveals remnants of the glacier, and which the narrator deciphers with the help of a map:

there's always more than just the keen pleasure of identification. There's the fact of these separate domains, each with its own history and reason [...] its pull on the imagination. The fact of these little countries lying snug and unsuspected, like and unlike as siblings can be, in a landscape that's usually disregarded, or dismissed as drab agricultural counterpane. It's the fact you cherish. (322, emphasis added)

Munro explicitly underlines the fact that such knowledge is to be cherished, suggesting her fondness for what may, on the surface, seem just unremarkable. Reading this assertion, one cannot but be reminded of Del Jordan's simile, "People's lives, in Jubilee as elsewhere, were dull, simple, amazing and unfathomable - like deep caves paved with kitchen linoleum" (Lives 249). As a recent essay on "the poetics of the linoleum" by Sabrina Francesconi shows, one never tires of looking at Munro's surfaces, from a crust of porridge that has dried on the floor (Dance 94) and that may clearly serve a proleptic function (90), to a swept and worn linoleum in an old farmhouse (Dance 11) that reveals the double nature of life, to ill-fitting or isolated squares of linoleum that will echo gaps and silences in a story (92). These surfaces always remind us of Munro's poetics, as they encapsulate her dialectical tensions, from the tension between the visible and the invisible, to that which exists between wholeness and fragmentation. To look at a landscape depicted by Munro and to read a Munro text is, as Héliane Ventura has suggested, “to take part in an archeological process which consists in recovering traces that have been abolished" (256).

Michel de Certeau's essay, The Practice of Everyday Life, may help to explain why Munro's stories can simultaneously include ordinary objects and point to what is not there, foreground details that can be seen and recall what cannot be seen anymore. He remarks that "memory is a sort of anti museum," it is "not localizable" and "fragments of it come out in legends" (106). Objects and places, therefore, "have hollow places in which a past sleeps" (108) while living spaces are haunted by the "presences of diverse absences" (108). Munro's "fiction of admission" will necessarily contain lists of ordinary objects that serve to recall someone's past. De Certeau draws an interesting connection between places and histories, places and stories: "Places are fragmentary and inward-looking histories [...], accumulated times that can be unfolded but like stories held in reserve, remaining in an enigmatic state, symbolizations encysted in the pain or pleasure of the body" (108, emphasis added). These are the connections that the essays in this special issue trace as well.

At a conference that took place at University of Paris Ouest Nanterre in April 2014, the participants were asked to consider Munro's "art of rehabilitating the hidden, the marginal, the disregarded, the disjunctive." They analyzed Munro's narrative strategies, motifs and techniques, paying particular attention to ordinary conversations, ordinary 
houses and trivial objects. In doing so, they tracked and traced the numerous faultlines, cracks, wounds, cysts and cavities that perforate her fiction. Ultimately, they showed that Munro's fiction is not so much about everyday life, as about life or, rather, as Munro herself has so beautifully captured it, writing "for dear life." The eight essays included in this volume show that Munro's stories, as Christine Berthin explains, offer a reflection on the reconstructive work of language that allows life to continue and engenders the process of healing at the heart of storytelling; they show that Munro's stories are also about defining her own material and poetics.

In "A Note on Utrecht Allegory," W. H. New offers a fresh perspective on one of Munro's earliest and, probably, most famous stories. He shows how a mere fragment, a single page from a school girl's composition on The Treaty of Utrecht, sheds light on the main questions the story raises, which, he posits, are about choice and absence of choice: who acts, and who cannot act? Who chooses or cannot bring herself to choose? The reference to a treaty that played a major role in Canadian history, provides an allegory to the story that depicts two young women from a small town in Canada who try to find a common ground after their mother's death. "Allegory" in the story sets in motion a mode of understanding, an acceptance of an order of life, with which the sisters must negotiate as they try to live their own lives. Eventually, underscoring details that reveal Munro's interest in her fictional town's colonial past, W. H. New argues that "The Peace of Utrecht" also offers an interesting comment on settlement, in both senses of the word.

"Forsaken Objects, Haunted Houses, Female Bodies, and 'the squalor of tragedy in ordinary life"' considers stories ranging from Munro's first collection to later stories, and analyzes Munro's various techniques for drawing attention to small, discarded or unsightly objects. Relying on Michel de Certeau's analysis of "the practice of everyday life," the essay considers the role played by such objects as remainders and reminders of people's lives. The essay also considers the connections Munro draws between unsightly features in the landscape, flawed female bodies and texts. The essay concludes on "Family Furnishings," a story which epitomizes Munro's reflection on her choice of material, since it foregrounds and unites the squalor of tragedy in ordinary people's lives and world literature.

Eleanora Rao devotes her essay "Home' and the Narrative of an Impossible Nostos" to "Home" from the 2006 collection, The View from Castle Rock. Rao analyzes the narrator's minute observations and descriptions of all the changes her father introduced in her former home, thus suggesting feelings of yearning for what is lost. Yet since hers is a gaze that defamiliarizes what was once very well known, the narrator's view of the renovated house does not lead to nostalgia; instead, it is ironic, inconclusive and fragmentary.

Two essays pay particular attention to conversational discourse, punctuation and rhythm. In her essay "When Secrets Become Weapons," Lucile Rouet-Bentley considers the function of secrets in "Before the Change" from The Love of a Good Woman (1998), showing that secrets are used as special weapons in the father-daughter relationship, until they deprive the male character of his power over his daughter. Secrets are rehabilitated, Lucile Bentley argues, because as the locus of irony, they no longer constitute a weakness but represent a means to endless reversals. She shows that in Munro's fiction, as epitomized by "Before the Change," secrets are also special tools for creation. 
Lynn Blin's essay, entitled "Sweet Dissonance in Alice Munro's 'The Progress of Love,' 'Friend of My Youth,' and 'Free Radicals"' looks at three stories ranging from the mid-1980s to 2009. Focusing on the introductory passages, Lynn Blin analyzes their oral dimensions, drawing attention to grammatical features which are vital clues to which the reader must be attuned in order to discover how the story coheres. She examines how the story lines and the open-ended resolutions that are apparently marked by dissonance can, in each story, be likened to a minor chord containing most of the "notes," echoing the jagged poignancy found in the opening pages.

Several essays are devoted to stories from Dear Life, which Munro published in 2012, and which may be her last published book. Isla Duncan's article "'A cavity everywhere': The Postponement of Knowing in 'Corrie" analyzes the various dexterous means by which Munro encourages the reader to take some (in)significant details into account the "bits and pieces of information" that prepare her readers for the final realization that strikes the protagonist at the end of the story. Isla Duncan concludes her essay by underscoring the ambiguity of the ending, which rests on a very short word, "it," and an ellipsis.

In "Alice Munro's Legacy: The 'Finale' of Dear Life" Mira Buchholtz argues that the last four pieces in the collection offer an example of legacy writing. They are to be read as examples of a writer's legacy, since they highlight heightened perception, altered states of mind, receptiveness to voices, and instinctive love of life, as Munro's narrators implicate themselves in the lives of others, sharing their emotions: in the "Finale" it is always other people who sing songs, write poems, leave legacies of their lives, and the narrator, holding on to her status of a wide-eyed child, becomes a receptacle for and a dispenser of other people's stories.

Christine Berthin's essay, "Of Wounds and Cracks and Pits: A Reading of Dear Life," considers the collection as a whole, as if it were an album, focusing on the themes that run through it. Christine Berthin shows that people full of "mended cracks" form a "recognizable pattern" in Munro's last collection, and she argues that wounds and cracks, which evoke the core of darkness that inhabits her stories, are the closest equivalent to the Lacanian Real. Particular attention is devoted to the gravel pit at the heart of "Gravel," a story characterized by gaps and contradictions. In her final sections, looking beyond the moments of destabilising pain foregrounded by the stories, Christine Berthin turns to the effects of the wounds in the construction of the subject and to various ways of mending the cracks through language. Ultimately, she demonstrates that Munro's last volume offers a reflection on the process of healing at the heart of storytelling, and on the reconstructive work of language that allows life to continue.

The volume concludes with an interview Elenor Wachtel conducted in 2004, for the CBC show, "Writers and Company," and which she has kindly permitted us to publish here in its complete version.

Corinne BIGOT

University of Paris-Ouest Nanterre 


\section{Works Cited}

De Certeau, Michel. The Practice of Everyday Life. Trans. S. Rendall, 1984. Berkeley and Los Angeles: U of California P, 2011. Trans. of L'invention du quotidien. 1980. Paris: Gallimard 1990.

Dutort, Thomas. "Literary Earth, Alice Munro's Ontario Geolithic." Etudes Canadiennes/ Canadian Studies 77 (2014): 77-109.

Francesconi, Sabrina. "Alice Munro and the Poetics of the Linoleum." The Inside of a Shell. Alice Munro's Dance of the Happy Shades. Ed. Vanessa Guignery. Newcastle upon Tyne: Cambridge Scholars Publishing, 2015. 86-97.

Hoy, Helen. "Alice Munro: 'Unforgettable, Indigestible Messages."' Journal of Canadian Studies 26.1 (Spring 1991): 5-21.

MilLER, Judith. "On Looking into Rifts and Crannies: Alice Munro's Friend of My Youth." The Antigonish Review 120 (2000): 205-26.

Munro, Alice. Lives of Girls and Women. 1971. London: Penguin, 1982.

—. "Open Secrets." Open Secrets. 1994. London: Chatto \& Windus, 1995. 3-51.

—. The View from Castle Rock. London: Chatto \& Windus, 2006.

—. "Interview with Mariella Frostrup." Open Book, BBC Radio Four. 16 Jan. 2005. <http://www.bbc. co.uk/radio4/arts/openbook/openbook_20050116.shtml>. Consulted Sept. 112014.

Toolan, Michael. "Introduction." Stylistic Perspectives on Alice Munro's Dance of the Happy Shades. Etudes de stylistique anglaise 8 (2015): 9-14.

Ventura, Héliane. “Alice Munro's Secret Ort.” Open Letter 11.9/12.1 (Fall-Winter 2003- 2004): 255-66.

The Nobel Prize in Literature 2013. "Bio-bibliography." Nobelprize.org. Nobel Media AB 2014. Web. 15. Apr. 2015. <http://www.nobelprize.org/nobel_prizes/literature/laureates/2013/bio-bibl. html> Consulted Oct. 102013. 